\title{
FAKTOR-FAKTOR YANG MEMPENGARUHI KEPUTUSAN UMKM MENGIKUTI RELAKSASI PAJAK DI MASA PANDEMI COVID-19
}

\author{
Ida Nurhayati ${ }^{1}$, Nurseto Adhi ${ }^{2}$ \\ 1,2 Politeknik Negeri Semarang, ida.nurhayati@polines.ac.id; \\ nurseto.adhi@polines.ac.id
}

\begin{abstract}
ABSTRAK
Riset ini bertujuan untuk menguji aspek-aspek yang mempengaruhi keputusan wajib pajak UMKM dalam mengambil program relaksasi pajak. Variabel riset terdiri dari variabel prosedur, pelayanan, dan pengetahuan sebagai variabel bebas. Kemudian keputusan wajib pajak UMKM mengikuti program relaksasi pajak sebagai variabel dependen. Tenik deskriptif digunakan dalam riset ini. Bentuk pendekatan yang dipergunakan ialah pendekatan kuantitatif dan kualitatif. Populasi dalam riset ini adalah pengusaha wajib pajak UMKM sebanyak 35 responden. Objek Penelitian ini tersebar di wilayah kota Bekasi, Blora, Boyolali, Ciamis, Getasan, Jakarta, Jepara, Salatiga, Kendal, Kudus, Lampung, Malang, Medan, Semarang, Wonogiri, dan Yogyakarta. Teknik pengambilan sampel yang dipergunakan ialah metoda purposive sampling. Teknik analisis yang digunakan riset ini adalah analisis regresi linear berganda dibantu dengan SPSS for window 23 sebagai alat analisis. Kesimpulan dalam riset membuktikan secara bersamaan variabel prosedur, pelayanan, dan pengetahuan berdampak terhadap keputusan wajib pajak UMKM mengikuti program relaksasi pajak UMKM mengikuti program relaksasi pajak. Sedangkan variabel pelayanan berpengaruh signifikan terhadap keputusan wajib pajak UMKM mengikuti program relaksasi pajak.
\end{abstract}

Kata Kunci: prosedur, pelayanan, pengetahuan, program relaksasi pajak

\begin{abstract}
This research aims to examining factors that influence the MSMEs taxpayer in taking the tax relaxation program. This research uses procedure, service, and knowledge as independent variables. Then the decision of MSMEs taxpayer to take the tax relaxation program as the dependen variabel. This research uses descriptive technique. The approach model that used in this research is quantitative and qualitative approaches. The population of this study were 35 MSMEs taxpayers. This research objects are scattered in the cities of Bekasi, Blora, Boyolali, Ciamis, Getasan, Jakarta, Jepara, Salatiga, Kendal, Kudus, Lampung, Malang, Medan, Semarang, Wonogiri, and Yogyakarta. The sampling technique was purposive sampling method. The analysis tecnique in this research is multiple linear regresion analysis with SPSS for window 23 as an analysis tool. The result of this research indicate that simultaneously the variables of procedure, service, and knowledge affected the decision of the MSMEs taxpayer to take the tax relaxation program. The procedure and knowledge as the independent variables were not affected significantly on the decision of MSMEs taxpayers to take the tax relaxation program. In other ways, the service variable affected significantly the decisions of to take the tax relaxation program.
\end{abstract}

Keywords: procedure, service, knowledge, the tax relaxation program

Naskah diterima : 03-03-2021, Naskah dipublikasikan : 30-04-2021 


\section{PENDAHULUAN}

Pandemi covid-19 tengah menimpa dunia tidak terkecuali Indonesia. Dimulai pada Desember 2019 hingga sekarang dunia sedang dihantam oleh pandemi covid-19 yang mengakibatkan krisis pada dunia industri. Indonesia sebelumnya pernah menghadapi krisis pada tahun 1998 lalu, pada waktu itu juga usaha mikro, kecil dan menengah (UMKM) menjadi pahlawan keuangan Indonesia dengan sumbangan ekspornya. Di era pandemi covid-19, UMKM diharapkan semakin maju dalam membangun perekonomian Indonesia. Akan tetapi, UMKM justru terkena dampak yang cukup telak dari adanya pandemi ini. Sebanyak $47 \%$ UMKM gulung tikar karena pandemi ini (bisnis.tempo.com). Kementerian Koperasi dan UKM menyebutkan lima klaster masalah yang dihadapi UMKM dimasa pandemi covid-19 adalah penjualan atau permintaan menurun, sulit bahan baku, distribusi atau operasional terhambat, dan permodalan, dan produksi terhambat .

Usaha mikro, kecil dan menengah (UMKM) sendiri tidak bisa dipandang sebelah mata. UMKM memiliki peranan yang vital pada perekonomian Indonesia karena pada tahun 2018 tercatat bahwa 60 juta unit UMKM memberi pengaruh pada PDB senilai 60,34\% \& sanggup menyerap pekerja hingga sebesar $97 \%$ dari jumlah pekerja secara nasional. Selain itu, ketahanan UMKM sudah terbukti pada guncangan krisis ekonomi tahun 1998 yang mana perusahaanperusahaan raksasa runtuh (merdeka.com). Sehingga, perlindungan terhadap sektor UMKM perlu dilakukan oleh pemerintah dimasa pandemi ini.

Pemerintah sebagai regulator sudah menyiapkan program penyelamatan UMKM dimasa pandemi ini berkoordinasi dengan pihak Kementerian Koperasi dan UKM. Pemerintah berupaya memberikan stimulus untuk pemberdayaan UMKM (Efriyenty et al., 2017). Salah satu programnya adalah program relaksasi pajak. Menurut peraturan Menteri Keuangan nomor 44/PMK.03/2020 birokrasi mengatur regulasi baru mengenai perpajakan yang didalamnya merupakan program penyelamatan UMKM. Melalui peraturan pemerintah tersebut Pph UMKM ditanggung pemerintah (DTP) berlangsung 6 bulan sejak April sampai dengan September 2020. Disusul oleh munculnya peraturan menteri keuangan nomor 9/PMK.03/2021 terkait insentif pajak untuk wajib pajak terimbas kasus corona virus disease 2019 bahwa insentif diperpanjang dari 02 februari 2021 sampai dengan 30 juni 2021. Program ini akan berjalan jika UMKM juga dapat menyambut dan mengurus persyaratan yang dibutuhkan ke kantor pajak pratama (KPP).

Penelitian mengenai faktor penyebab wajib pajak mengikuti kebijakan dan program pemerintah pernah dilakukan. Penelitian yang dilaksanakan oleh K. Lely dan Gusti (2018) menemukan bahwa kesadaran wajib pajak, pengetahuan pajak wajib pajak, pelayanan fiskus dan sanksi pajak berpengaruh baik terhadap kesediaan wajib pajak mengikuti tax amnesty. Kebijakan tax amnesty ialah merupakan alternative cara memperbaikan perpajakan dan meningkatakan tax compliance dengan memberikan kesempatan kepada wajib pajak guna memenuhi kewajibannya secara baik dan membuat database akurat (kemenkeu.go.id, 2017). Penelitian K. Lely dan Gusti (2018) meneliti mengenai faktor penyebab kemauan wajib pajak mengikuti tax amnesty.

Serupa dengan penelitian yang dilakukan K. Lely dan Gusti (2018), Penelitian ini mengidentifikasikan faktor yang mempengaruhi keputusan pemilik UMKM sebagai wajib pajak dalam mengikuti program relaksasi pajak dari pemerintah dimasa pandemi covid-19. Temuan penelitian ini dapat memberikan paparan yang lebih efisien kepada pemerintah apakah program relaksasi pajak yang diberikan sudah maksimal dimanfaatkan oleh UMKM atau memiliki kendala dalam pelaksanaannya. Penelitian ini akan fokus pada masalah pengetahuan program oleh UMKM, prosedur program dan layanan kantor pajak pratama (KPP) dalam program relaksasi pajak ini. Pemerintah diharapkan dapatkan membuat program ini berjalan lebih baik dan mengatasi kendala-kendala yang dihadapi UMKM, sehingga pemberian KUR dimasa covid-19 ini dapat terserap maksimal. 


\section{KAJIAN LITERATUR}

\section{Usaha Mikro, Kecil, dan Menengah (UMKM)}

Menurut Undang-Undang Nomor 20 Tahun 2008 terkait Usaha Mikro, Kecil, dan Menengah (UMKM) yang dirincikan dibawah ini:

a. Usaha mikro merupakan bisnis produktif yang dimiliki perseorangan atau bandan usaha perseorangan dan telah mencukupi persyaratan usaha mikro yang mana diatur dalam undang-undang ini.

b. Usaha kecil ialah bisnis ekonomi produktif yang mandiri yang dioperasikan oleh per individu atau kelompok badan bisnis \& tidak di operasikan menjadi anak perusahaan atau bukan cabang perusahaan yang dipunyai, dikendalikan, atau secarsa langsung atau tidak langsung berawal dari bisnis menengah atau besar yang terpenuhi kriteria usaha kecil dalam aturan ini.

c. Usaha menengah mengacu pada usaha ekonomi berorientasi produksi yang mandiri yang dioperasionalkan oleh indivudu atau kelompok usaha yang tidak secara langsung atau tak langsung memiliki, mengendalikan atau bukan perusahaan kecil atau besar dengan aset bersih atau pendapatan penjualan hukum ini pasal 6 undang-undang nomor 20 tahun 2018 membagi kriteria usaha mikro, kecil \& menengah seperti ditunjukkan tabel 1 berikut ini:

Tabel 1. Kriteria-Kriteria UMKM

\begin{tabular}{|c|l|l|l|}
\hline \multirow{2}{*}{ No } & \multicolumn{1}{|c|}{ Uraian } & \multicolumn{1}{|c|}{ Kriteria } \\
\cline { 3 - 4 } & & \multicolumn{1}{|c|}{ Aktiva } & \multicolumn{1}{c|}{ Pendapatan } \\
\hline 1. & Usaha Mikro & Maksimal 50 juta & Masimal 300 juta \\
\hline 2. & Usaha Kecil & Lebih 50 juta -500 juta & Lebih 300 juta- 2,5 miliar \\
\hline 3. & Usaha Menengah & Lebih 500 juta-10 miliar & Lebih 2,5-50 miliar \\
\hline
\end{tabular}

Sumber: www.depkop.go.id

\section{Covid -19 di Indonesia}

Covid-19 adalah coronavirus disease yaitu sebuah penyakit dengan tingkat penularan akut yang dikarenakan oleh corona virus yang menggemparkan dunia. Sehingga mengakibatkan Covid-19 mewabah utamanya melalui orang yang terinfeksi batuk, bersin, atau menghembuskan nafas. Covid-19 mulai masuk di Indonesia pada bulan Februari 2020. Hingga sekarang per tanggal 08 Februari 2021, Indonesia sudah tercatat 1.166 .079 orang positif, 963.028 orang sembuh dan 31.763 orang meninggal dunia (covid19.go.id).

Berbagai negara sudah melakukan berbagai macam tindakan pencegahan menyebarnya covid-19. Di Indonesia langkah pencegahan untuk meminimalisir penyebaran adalah dilakukannya pembatasan sosial berskala besar (PSBB). Dampak dari pemberlakuan tersebut adalah sejumlah usaha harus berhenti beroperasi karena untuk menerapkan salah satu himbauan pemerintah yaitu social distancing atau phsycal distancing. Akibat dari penghentian operasi tersebut banyak usaha yang mengalami kerugian bahkan hingga harus gulung tikar. Selain masalah operasional, masalah daya beli masyarakat yang berkurang, larangan berpergian yang menyebabkan distribusi terganggu dan masalah lain yang akan berdampak pada krisis keuangan pada dunia usaha.

Hal ini tidak hanya berdampak pada industri besar, bagi UMKM yang terdahulu dapat bertahan dari krisis 1998 sekarang juga kena dampaknya. Terdapat 47\% UMKM akan mengalami kebangkrutan akibat krisis pandemi covid-19 ini (tempo.com). Jika dilihat dari data UMKM tahun 2018 sebesar 64.194.057 maka angka UMKM yang bangkrut adalah sebesar 30.171.207 unit. Jumlah tersebut tentulah bukan jumlah yang sedikit, karena juga berimbas pada penghentian hubungan kerja dengan tenaga kerja yang telah terserap. Oleh karena itu diperlukan bantuan khusus pemerintah untuk dapat mengatasinya. 


\section{Program Relaksasi Pajak}

Terdapat sembilan program mitigasi dampak negatif covid-19 yang dijabarkan oleh Kemeterian Koperasi dan UKM. Salah satu programnya adalah relaksasi pajak yang perihal pajak penghasilan pasal 21, pajak penghasilan impor, pajak penghasilan pasal 25, restitusi pajak PPN dapat direlaksasi untuk UMKM pada program ke 9 (kemenkopukm.go.id). Berdasarkan kemenkeu.go.id disampaikan bahwa program relaksasi pajak sebagai berikut ini:

a. Relaksasi yang ke-satu ialah birokrasi memberi keringanan pajak atas pph pasal 21 secara keseluruhan pegawai industry pengolahan dan manufaktur yang pendapatan tahunannya hingga 200 juta baik industry yang berlokasi di wilayah industry tujuan ekspor (KITE) maupun industry dengan pendapatan ekspor tahunan (non KITE). Birokrasi memberi keringanan pph pasal 21 ini selama 6 bulan mulai bulan april hingga September 2020.

b. Relaksasi yang ke-dua adalah relaksasi pajak penghasilan pasal 22 impor untuk Sembilan belas industry manufaktur semenjak April sampai September tahun 2020 diberikan kelonggaran atau keringanan selama 6 bulan baik untuk industry manufaktur di kawasan KITE maupun non KITE.

c. Relaksasi yang ke-tiga adalah birokrasi memberlakukan penundaan pajak penghasilan pasal 25 untuk perusahaan yang berada di wilayah KITE maupun non KITE selama 6 bulan mulai April sampai September.

d. Relaksasi yang ke-empat adalah birokrasi melakukan percepatan restitusi terkait pajak pertambahan nilai (PPN) bahkan tanpa preliminary review. Namun, jika ada yang perlu diperiksa, maka dilakukan pemeriksaan lebih lanjut. Birokrasi akan memberikan pelayanan istimewa tersebut hingga 6 bulan dari April sampai September 2020.

\section{Prosedur}

Pendapat Mulyadi (2013), Prosedur merupakan serangkaian aktivitas klerikal, pada umumnya mengikutkan lebih dari satu individu dalam satu departemen yang dimaksudkan guna memastikan penanggulangan merata terhadap transaksi corporate yang terjadi berulangkali. Dalam pengajuan relaksasi pajak di KPP pada masa covid-19 ini pasti akan ada tahapan kegiatan yang harus dilakukan oleh wajib pajak. Adanya prosedur pengurusan yang lebih mudah dan baik akan meningkatkan keputusan wajib pajak UMKM dalam melakukan atau memperoleh relaksasi pajak. Menurut Lubis dan Mahalli (2014), Indikasi prosedur merupakan salah satu faktor vital berdampak bagi pebisnis.

H1: Prosedur berpengaruh signifikan terhadap keputusan wajib pajak UMKM mengikuti program relaksasi pajak.

\section{Pelayanan}

Kotler (2002), menjelaskan jika pelayanan merupakan setiap perilaku atau aktivitas bisa ditawarkan oleh suatu orang kepada orang atau pihak lain yang dasarnya intangible serta tidak mengakibatkan kepunyaan yang dimiliki. Pelayanan yang berkualitas atau baik dalam suatu program akan meningkatkan keputusan seseorang untuk mengikuti program tersebut. Tjiptono (2007), mengartikan kualitas pelayanan sebagai tindakan dalam mencukupi kebutuhan dan kemauan pelanggan sehingga tepat dalam penyampaian agar selaras dengan harapan pelanggan. Pelayanan benar, cepat dan memudahkan konsumen dalam situasi ini adalah wajib pajak akan meningkatkan keputusan wajib pajak untuk mengikuti program ini. Dengan begitu akan semakin banyak UMKM yang tertolong untuk tidak gulung tikar. Othman dan Owen (2001), Berpendapat bahwa service quality since satisfaction is particularly sensitive to the level of service quality provided by the organization.

$\mathrm{H} 2$ : Pelayanan berpengaruh signifikan terhadap keputusan wajib pajak UMKM mengikuti program relaksasi pajak.

\section{Pengetahuan}

Mowen dan Minor (1998), mengartikan pengetahuan konsumen (consumer knowledge) menjadi banyak experience \& information yang dimiliki seseorang terkait product atau 
pelayanan. Peter dan Oslon (2010), menyatakan 4 faktor pada pengetahuan produk yakni: kelengkapan produk, kegunaan fungsional, kegunaan psikologis dan value didapat jika pelanggan menggunakan product atau pelayanan product jasa. Pengetahuan wajib pajak terhadap program relaksasi pajak ini akan mempengaruhi keputusan wajib pajak untuk mengikuti program ini. Knowledge level tinggi memiliki daya ingat lebih efektif dan efesien, pengakuan, analisis, dan kemampuan penalaran bagus dibandingkan dengan knowledge tergolong rendah (Manuarang dan Mawardi, 2018). Hal ini dikarenakan wajib pajak mengetahui atribut program dan manfaat kegunaan program ini bagi usahanya.

H3: Pengetahuan berpengaruh signifikan terhadap keputusan wajib pajak UMKM mengikuti program relaksasi pajak.

\section{METODE PENELITIAN}

Teknik deskriptif digunakan pada riset ini. Bentuk pendekatan yang dilakukan dalam riset ini ialah pendekatan kuantitatif \& kualitatif. Riset ini menggunakan bentuk pengumpulan data berbentuk daftar pertanyaan (kuesioner) yang diberikan menggunakan fasilitas e-form dikarenakan keberadaan pandemi covid-19 yang sedang terjadi baru-baru ini sehingga mematuhi himbauan social distancing dari pemerintah. Kuesioner dilakukan dengan skala likert setuju dan tidak setuju dengan skor 1-5.

Penelitian ini menggunakan populasi pengusaha wajib pajak UMKM sebanyak 35 responden dengan objek penelitian yang tersebar di wilayah kota Bekasi, Blora, Boyolali, Ciamis, Salatiga, Jakarta, Kendal, Kudus, Lampung, Malang, Medan, Semarang, Wonogiri \& Yogyakarta. Teknik pengambilan sampel pada bentuk purposive sampling dengan memperhatikan ukuran yang menjadi standar penelitian ini: UMKM yang bersedia memberikan informasi yang dibutuhkan pada riset dan UMKM memiliki data-data sesuai yang diperlukan pada riset ini.

Teknik analisa mempergunakan analisa refresi linear berganda dibantu SPSS for window 23 sebagai alat analisis. Tahapan-tahapan dalam analisa regresi linear berganda untuk riset primer adalah: Uji validitas, diperlukan guna menaksir sah dan valid tidaknya daftar pertanyaan (kuesioner). Pertanyaan (kuesioner) dikatakan absolut apabila pertanyaan kuesioner mumpuni mengungkapakan suatu yang akan diperkirakan datanya oleh kuesioner tersebut. Uji Reliabilitas, pengujian ini dipergunakan menaksir suatu pernyataan kuesioner yang menjadi penanda dari variabel atau konstruk. Pernyataan kuesioner dikategorikan reliabel apabila jawaban individu pada pertanyaan ialah konsisten secara time series. Uji asumsi klasik, pengujian ini dipergunakan untuk meyakinkan bahwa sampel terbebas dari gangguan normalitas, multikolonieritas, autokorelasi, dan heterokesdatisitas. Uji kelayakan model, pengujian ini terdiri dari uji signifikan parameter individual (uji statistik t) dan koefesien determinasi (Ghozali, 2011).

\section{PEMBAHASAN}

\section{Gambaran Umum Objek Penelitian}

Dibawah ini adalah data responden sesuai dengan gender:

Tabel 2. Gender

\begin{tabular}{|l|c|c|c|c|}
\hline & Frekuensi & Prosentase & rosentase Valid & Kumulatif \\
\hline Pria & 20 & 57,1 & 57,1 & 57,1 \\
\hline Wanita & 15 & 42,9 & 42,9 & 100,0 \\
\cline { 1 - 4 } \multicolumn{1}{|c|}{ Total } & 35 & 100,0 & 100,0 & \\
\hline
\end{tabular}

Sumber: Data SPSS telah diolah (2021)

Hasil dari data tabel 2 pada riset ini menunjukkan bahwa gender responden pria sejumlah $57,1 \%$ dan wanita sejumlah $42,9 \%$. 


\section{Data Responden Berdasarkan Jenis Usaha}

Tabel 3. Jenis Usaha

\begin{tabular}{|l|c|c|c|c|}
\hline \multicolumn{1}{|c|}{ Jenis Usaha } & Frekuensi & Prosentase & Prosentase Valid & Kumulatif \\
\hline Batik & 1 & 2,9 & 2,9 & 5,7 \\
\hline Dagang & 2 & 5,7 & 5,7 & 8,6 \\
\hline Dagang Madu & 1 & 2,9 & 2,9 & 11,4 \\
\hline $\begin{array}{l}\text { Dagang Syur } \\
\text { Keliling }\end{array}$ & 1 & 2,9 & 2,9 & 14,3 \\
\hline Fashion & 1 & 2,9 & 2,9 & 17,1 \\
\hline Jasa & 1 & 2,9 & 2,9 & 20,0 \\
\hline $\begin{array}{l}\text { Jasa Konsultan } \\
\text { Keuangan }\end{array}$ & 1 & 2,9 & 2,9 & 22,9 \\
\hline Jasa Perpajakan & 1 & 2,9 & 2,9 & 25,7 \\
\hline $\begin{array}{l}\text { Jasa Sertifikasi } \\
\text { Usaha, Konsul }\end{array}$ & 1 & 2,9 & 2,9 & 28,6 \\
\hline Jual Beli & 1 & 2,9 & 2,9 & 31,4 \\
\hline Kebutuhan Bayi & 1 & 2,9 & 2,9 & 34,3 \\
\hline Kecantikan & 1 & 2,9 & 2,9 & 37,1 \\
\hline Kerajinan & 1 & 2,9 & 2,9 & 40,0 \\
\hline Konter & 1 & 2,9 & 2,9 & 42,9 \\
\hline $\begin{array}{l}\text { Kredit Kebutuhan } \\
\text { Rumah Tangga }\end{array}$ & 1 & 2,9 & 2,9 & 45,7 \\
\hline Kuliner & 1 & 2,9 & 2,9 & 48,6 \\
\hline $\begin{array}{l}\text { Kuliner,Fashion, } \\
\text { Home Dekor }\end{array}$ & 1 & 2,9 & 2,9 & 51,4 \\
\hline Makanan & 1 & 2,9 & 2,9 & 54,3 \\
\hline Makanan Ringan & 3 & 8,6 & 8,6 & 62,9 \\
\hline Manufaktur & 1 & 2,9 & 2,9 & 65,7 \\
\hline Penjahit & 1 & 2,9 & 2,9 & 68,6 \\
\hline $\begin{array}{l}\text { Perbaikan,Pengadaa } \\
\text { n Mesin }\end{array}$ & 1 & 2,9 & 2,9 & 71,4 \\
\hline Perdagangan & 1 & 2,9 & 2,9 & 74,3 \\
\hline Perkebunan & 1 & 2,9 & 2,9 & 77,1 \\
\hline $\begin{array}{l}\text { Perlengkapan } \\
\text { Rumah Tangga }\end{array}$ & 1 & 2,9 & 2,9 & 80,0 \\
\hline Peternakan & 2 & 5,7 & 5,7 & 85,7 \\
\hline Sablon Kaos & 1 & 2,9 & 2,9 & 88,6 \\
\hline $\begin{array}{l}\text { Supplier Gazebo } \\
\text { dan Furnitur }\end{array}$ & 1 & 2,9 & 2,9 & 91,4 \\
\hline Teknologi & 1 & 2,9 & 2,9 & 94,3 \\
\hline $\begin{array}{l}\text { Teknologi } \\
\text { Informasi }\end{array}$ & 2,9 & 2,9 & 97,1 \\
\hline Transportasi & 100,0 & 100,0 & 100,0 \\
\hline Sumber Dan & & & \\
\hline
\end{tabular}

Sumber: Data SPSS telah diolah (2021).

Hasil atas tabel 3 menyatakan jika bidang atau jenis usaha responden beragam dari usaha dibidang perdagangan: batik, madu, sayur keliling, fashion, jual beli, kebutuhan bayi, kerajinan, konter, kredit kebutuhan rumah tangga, kuliner, dekorasi, makanan, manufaktur, mesin, perkenunan, peternakan, sablon kaos, supplier gazebo \& furniture. Selanjutnya usaha dibidang 
jasa terdapat jasa konsultan keuangan, jasa perpajakan, jasa penjahit, jasa pengadaan mesin, jasa kecantikan, jasa sertifikasi, jasa transportasi \& jasa teknologi informasi.

\section{Data Responden Berdasarkan Penghasilan Pertahun}

Tabel 4. Penghasilan Pertahun

\begin{tabular}{|c|c|c|c|c|}
\hline & Frekuensi & Prosentase & Prosentase Valid & Kumulatif \\
\hline <300 Juta & 28 & 80,0 & 80,0 & 80,0 \\
\hline 300 Juta s/d 2,5 Miliar & 6 & 17,1 & 17,1 & 97,1 \\
\hline 2,5 Milyar s/d 50 Miliar & 1 & 2,9 & 2,9 & 100,0 \\
\hline Jumlah & 35 & 100,0 & 100,0 & \\
\hline
\end{tabular}

Sumber: Data SPSS telah diolah (2021)

Hasil tabel 4 menyatakan bahwa dari kategori penghasilan pertahun responden $<300$ juta terdapat total $80 \%$, kemudian kategori 300 juta hingga 2,5 miliar terdapat total $17,1 \%$ dan kategori penghasilan pertahun 2,5 miliar hingga 50 miliar terdapat total $2,9 \%$.

\section{Data Responden Berdasarkan Kota}

Tabel 5. Kota Tempat Usaha

\begin{tabular}{|l|c|c|c|c|}
\hline \multicolumn{1}{|c|}{ Kota } & Frekuensi & Prosentase & Prosentase Valid & Kumulatif \\
\hline Bekasi & 1 & 2,9 & 2,9 & 2,9 \\
\hline Blora & 1 & 2,9 & 2,9 & 5,7 \\
\hline Boja,Semarang & 1 & 2,9 & 2,9 & 8,6 \\
\hline Boyolali & 2 & 5,7 & 5,7 & 14,3 \\
\hline Ciamis & 1 & 2,9 & 2,9 & 17,1 \\
\hline $\begin{array}{l}\text { Getasan, } \\
\text { Salatiga }\end{array}$ & 1 & 2,9 & 2,9 & 20,0 \\
\hline Jakarta & 3 & 8,6 & 8,6 & 28,6 \\
\hline Jepara & 1 & 2,9 & 2,9 & 31,4 \\
\hline $\begin{array}{l}\text { Kecandran, } \\
\text { Salatiga }\end{array}$ & 1 & 2,9 & 2,9 & 34,3 \\
\hline Kendal & 2 & 5,7 & 5,7 & 40,0 \\
\hline Kudus & 1 & 2,9 & 2,9 & 42,9 \\
\hline Lampung & 1 & 2,9 & 2,9 & 45,7 \\
\hline Malang & 1 & 2,9 & 2,9 & 48,6 \\
\hline Medan & 11 & 5,7 & 5,7 & 54,3 \\
\hline Semarang & 1 & 2,9 & 2,9 & 88,6 \\
\hline Wonogiri & 4 & 11,4 & 11,4 & 100,0 \\
\hline Yogyakarta & 35 & 100,0 & 100,0 & \\
\hline \multicolumn{1}{|c|}{ Total } & & & \\
\hline
\end{tabular}

Sumber: Data SPSS telah diolah (2021)

Hasil tabel 5 menyatakan jika objek penelitian tersebar di beberapa wilayah yaitu kota Bekasi, Blora, Boja (Semarang), Boyolali, Ciamis, Getasan, Jakarta, Jepara, Kecandran (Salatiga), Kendal, Kudus, Lampung, Malang, Medan, Semarang, Wonogiri \& Yogyakarta. 


\section{Data Responden Berdasarkan Usaha Terdampak Covid-19}

Tabel 6. Usaha Terdampak Covid-19

\begin{tabular}{|l|r|r|r|r|}
\hline & Frekensi & Prosentase & Prosentase Valid & Kumulatif \\
\hline Ya & 30 & 85,7 & 85,7 & 85,7 \\
\hline Tidak & 5 & 14,3 & 14,3 & 100,0 \\
\cline { 1 - 3 } Total & 35 & 100,0 & 100,0 & \\
\hline
\end{tabular}

Sumber: Data SPSS telah diolah (2021)

Hasil tabel 6 pada penelitian ini menandakan sebanyak 85,7\% responden terdampak covid-19 sedangkan $14,3 \%$ tidak mengalami dampak pandemi.

\section{Data Responden Berdasarkan Omset Penjualan Terdampak Covid-19}

Tabel 7. Omset Terdampak Covid-19

\begin{tabular}{|l|c|c|c|c|}
\hline & Frekuensi & Prosentase & Prosentase Valid & Kumulatif \\
\hline $\begin{array}{l}\text { Penjualan Berkurang } \\
0-25 \%\end{array}$ & 2 & 5,7 & 5,7 & 5,7 \\
\hline $\begin{array}{l}\text { Penjualan Berkurang } \\
\text { 26\%-50\% }\end{array}$ & 22 & 62,9 & 62,9 & 68,6 \\
\hline $\begin{array}{l}\text { Penjualan Berkurang } \\
76 \%-100 \%\end{array}$ & 6 & 17,1 & 17,1 & 85,7 \\
\hline $\begin{array}{l}\text { Usaha Berhenti } \\
\text { Operasi }\end{array}$ & 5 & 14,3 & 14,3 & 100,0 \\
\hline \multicolumn{1}{|c|}{ Total } & 35 & 100.0 & 100,0 & \\
\hline
\end{tabular}

Sumber: Data SPSS telah diolah (2021)

Hasil tabel 7 menjelaskan jika usaha responden mengalami penurunan penjualan kategori 0-25\% sebesar 5,7\%. Kemudian penjualan berkurang kategori 26\%-50\% sebesar $62,9 \%$. Selanjutnya usaha responden penjualan berkurang kategori 76\%-100\% sebesar 17,1\%. Serta usaha responden kategori behenti beroperasi sejumlah 14,3\%.

\section{Analisis Data}

Tabel 8. Descriptive Statistics

\begin{tabular}{|l|c|c|c|c|c|}
\hline & N & Minimum & Maksimal & $\begin{array}{c}\text { Rata- } \\
\text { Rata }\end{array}$ & $\begin{array}{c}\text { Standar } \\
\text { Deviasion }\end{array}$ \\
\hline Prosedur & 35 & 5,00 & 25,00 & 17,4000 & 5,57937 \\
\hline Pelayanan & 35 & 6,00 & 30,00 & 21,2857 & 6,28524 \\
\hline Pengetahuan & 35 & 5,00 & 25,00 & 17,6857 & 6,68084 \\
\hline $\begin{array}{l}\text { Keputusan } \\
\text { Wajib Pajak }\end{array}$ & 35 & 5,00 & 25,00 & 17,7714 & 6,11693 \\
\hline $\begin{array}{l}\text { Valid N } \\
\text { (listwise) }\end{array}$ & 35 & & & & \\
\hline
\end{tabular}

Sumber: Data SPSS telah diolah (2021)

Hasil tabel 8 menyatakan jika variabel prosedur memiliki nilai paling rendah 5 \& value paling tinggi 25 . Kemudian nilai rata-rata 17,4000 dan standar deviasi sebesar 21,57937. Variabel pelayanan memiliki nilai paling rendah 6 dan nilai paling tinggi 30 dengan nilai rata-rata sebesar 21,2857 serta standar deviasi 6,28524. Variabel pengetahuan memiliki nilai minimum sebesar 5 dan nilai maksimal 25 dengan bilai rata-rata sebesar 17,7714 serta nilai standar deviasi sebesar 6,11693 . 


\section{Uji Validitas}

Tabel 9. Uji Validitas

\begin{tabular}{|c|c|c|c|c|}
\hline Variabel & Item & $\begin{array}{c}\text { Pearson } \\
\text { Correlation }\end{array}$ & r tabel & Keterangan \\
\hline \multirow{5}{*}{ Prosedur } & X1.1 & 0,929 & 0,3338 & Valid \\
\cline { 2 - 5 } & X1.2 & 0,831 & 0,3338 & Valid \\
\cline { 2 - 5 } & X1.3 & 0,794 & 0,3338 & Valid \\
\cline { 2 - 5 } & X1.4 & 0,955 & 0,3338 & Valid \\
\cline { 2 - 5 } & X1.5 & 0,948 & 0,3338 & Valid \\
\hline \multirow{5}{*}{ Pelayanan } & X2.1 & 0,819 & 0,3338 & Valid \\
\cline { 2 - 5 } & X2.2 & 0,889 & 0,3338 & Valid \\
\cline { 2 - 5 } & X2.3 & 0,902 & 0,3338 & Valid \\
\cline { 2 - 5 } & X2.4 & 0,953 & 0,3338 & Valid \\
\cline { 2 - 5 } & X2.5 & 0,928 & 0,3338 & Valid \\
\cline { 2 - 5 } Pengetahuan & X2.6 & 0,945 & 0,3338 & Valid \\
\hline & X3.1 & 0,790 & 0,3338 & Valid \\
\cline { 2 - 5 } & X3.2 & 0,972 & 0,3338 & Valid \\
\cline { 2 - 5 } & X3.3 & 0,965 & 0,3338 & Valid \\
\cline { 2 - 5 } & X3.4 & 0,977 & 0,3338 & Valid \\
\cline { 2 - 5 } & X3.5 & 0,957 & 0,3338 & Valid \\
\hline \multirow{5}{*}{$\begin{array}{l}\text { Keputusan } \\
\text { Wajib Pajak }\end{array}$} & Y.1 & 0,934 & 0,3338 & Valid \\
\cline { 2 - 5 } UMKM & Y.2 & 0.950 & 0,3338 & Valid \\
\cline { 2 - 5 } & Y.3 &, 0962 & 0,3338 & Valid \\
\cline { 2 - 5 } & Y.4 & 0,893 & 0,3338 & Valid \\
\cline { 2 - 5 } & Y.5 & 0,924 & 0,3338 & Valid \\
\hline
\end{tabular}

Sumber : Data SPSS telah diolah (2021)

Hasil tabel 9 menyatakan jika uji validitas terhadap variabel prosedur, pelayanan, pengetahuan dan keputusan wajib pajak UMKM pada semua pertanyaan mempunyai value pearseon correlation yang $>$ dari $\mathrm{r}$ tabel yang dirumuskan $(\mathrm{d} f=\mathrm{n}-2)$. Sehingga masing-masing item variabel dijelaskan valid dengan persyaratan validitas tercukupi.

\section{Uji Reliabilitas}

Tabel 10. Uji Reliabilitas

\begin{tabular}{|l|c|c|}
\hline \multicolumn{1}{|c|}{ Variabel } & $\begin{array}{c}\text { Cronbach } \\
\text { Alpha }\end{array}$ & Keterangan \\
\hline Prosedur & 0,936 & Reliabel \\
\hline Pelayanan & 0,956 & Reliabel \\
\hline Pengetahuan & 0,962 & Reliabel \\
\hline $\begin{array}{l}\text { Keputusan } \\
\begin{array}{l}\text { Wajib Pajak } \\
\text { UMKM }\end{array}\end{array}$ & 0,962 & Reliabel \\
\hline
\end{tabular}

Sumber : Data SPSS telah diolah (2021)

Hasil tabel 10 menyatakan jika uji reliabilitas variabel Prosedur, Pelayanan, Pengetahuan dan Keputusan Wajib Pajak telah mendapatkan nilai cronbach alpha lebih dari 0,70 sehingga dinyatakan reliabel.

\section{Uji Asumsi Klasik}

Uji asumsi klasik ialah kriteria statistik wajib dilengkapi dalam riset analisa regresi linear berganda. Menurut Ghozali (2011) dasar uji normalitas yaitu dengan nilai nonparametrik kolmogorov-smirnov, apabila value Sig lebih 0,05 maka dapat dikategorikan data 
telah berditribusi normal sedangkan apabila value Sig kurang dari 0,05 sehingga data bisa dikategorikan tidak berdistribusi normal.

Tabel 11. Uji Asumsi Klasik

\begin{tabular}{|l|c|c|c|c|c|c|}
\hline \multicolumn{1}{|c|}{ Variabel } & $\begin{array}{c}\text { t } \\
\text { Hitung }\end{array}$ & Sig & Tolerance & VIF & $\begin{array}{c}\text { Nilai } \\
\text { Autokorelasi }\end{array}$ & Keterangan \\
\hline Prosedur & 0,006 & 0,996 & 0,186 & 5,373 & & $\begin{array}{c}\text { Bebas } \\
\text { Multikolonieritas } \\
\& \\
\text { Heteroskedastisitas }\end{array}$ \\
\hline Pelayanan & $-0,625$ & 0,536 & 0,207 & 4,825 & & $\begin{array}{c}\text { Bebas } \\
\text { Multikolonieritas } \\
\&\end{array}$ \\
Pengetahuan & $-0,268$ & 0,791 & 0,369 & 2,707 & & $\begin{array}{c}\text { Heteroskedastisitas } \\
\text { Bebas } \\
\text { Multikolonieritas } \\
\&\end{array}$ \\
\hline $\begin{array}{l}\text { Asymp. Sig. } \\
\text { (2-tailed) }\end{array}$ & & & & & 0,996 & \\
\hline
\end{tabular}

Sumber : Data SPSS telah diolah (2021)

Tabel 11 menyimpulkan pada penelitian ini menyatakan jika data penelitian sudah terdistribusi normal. Menurut Ghozali (2011) model regresi dinyatakan benar adalah jika tidak terdapat hubungan antara variabel bebas, apabila variabel independen menunjukkan nilai tolerance $>0,10$ dan nilai VIF $<10$ maka dapat dikatakan model regresi bebas dari masalah multikolonieritas. Pada data penelitian ini menyatakan bahwa variabel Prosedur, Pelayanan, dan Pengetahuan memiliki nilai tolerance $>0,10$ dan nilai VIF $<10$ dapat dikatakan tidak terdapat gejala multikolonieritas. Serta nilai Sig $>0,05$ sehingga bebas dari gejala heteroskedastisistas. Menurut Ghozali (2011) uji autokorelasi memakai run-test memiliki kriteria apabila nilai Sig >0,05 maka tidak terdapat pertanda autokorelasi menunjukkan value asymp.sig. (2-tailed) sebesar 0,996 >0,05 sehingga bisa dikatakan pasti bebas dari pertanda autokorelasi.

\section{Analisis Uji Regresi Linear Berganda}

Tabel 12. Uji Linear Berganda

\begin{tabular}{|c|c|c|c|}
\hline \multirow[b]{2}{*}{ Model } & \multicolumn{2}{|c|}{ Unstandardized Coefficients } & $\begin{array}{c}\text { Standardized } \\
\text { Coefficients } \\
\end{array}$ \\
\hline & B & Std. Error & Beta \\
\hline (Constant) &,- 186 & 1,905 & \\
\hline Prosedur & ,324 & ,224 & ,296 \\
\hline Pelayanan & ,495 & ,188 & ,509 \\
\hline Pengetahuan & , 100 & ,133 &, 110 \\
\hline
\end{tabular}

Sumber : Data SPSS telah diolah (2021)

Berdasarkan tabel 12 menyatakan perumusan regresi yang diperoleh pada penelitian ini antara lain:

$$
\text { KWP = -0,186 + 0,324PRO + 0,495PEL + 0,100PENG + e }
$$

Dari rumus regresi diatas maka dapat diinterpretasikan bahwa nilai koefisiaen variabel prosedur bernilai positif sebesar 0,324 sehingga apabila variabel prosedur naik satu satuan maka keputusan wajib pajak UMKM inflasi sebesar 0,324.Variabel pelayanan bernilai positif sebesar 0,495 
sehingga apabila variabel pelayanan naik satu satuan maka keputusan wajib pajak UMKM mengikuti program relaksasi pajak akan naik sebesar 0,495. Variabel pengetahuan bernilai positif sebesar 0,100 sehingga apabila variabel Pengetahuan naik satu satuan maka keputusan wajib pajak UMKM mengikuti program relaksasi pajak akan naik sebesar 0,100.

\section{Uji F}

Uji $\mathrm{F}$ bertujuan mengecek kelayakan model regresi linear berganda pada pengujian pengaruh antara variabel bebas dan variabel terikat. Pengujian dijalankan menggunakan nilai Sig $<0,05$.

Tabel 13. Uji Simultan (Uji F)

\begin{tabular}{|c|c|c|}
\hline Model & F & Sig. \\
\hline $\begin{array}{c}\text { Regression } \\
\text { Residual } \\
\text { Total }\end{array}$ & 32.652 & $.000^{\mathrm{b}}$ \\
\hline
\end{tabular}

Sumber : Data SPSS telah diolah (2021)

Hasil tabel 13 menyatakan value Sig < 0,05 sehingga variabel independen yakni variabel prosedur, pelayanan dan pengetahuan mempengaruhi signifikan secara bersamaan terhadap variabel keputusan wajib pajak UMKM mengikuti program relaksasi pajak.

\section{Uji t}

Uji $\mathrm{t}$ bertujuan bagaimana korelasi satu variabel bebas dalam memperjelaskan variabel terikat. Level signifikan yang dipakai pada riset ini ialah senilai 0,05 . Berikut ini merupakan kesimpulan pengolahan uji $\mathrm{t}$ :

Tabel 14. Uji t

\begin{tabular}{|l|c|c|c|}
\hline \multicolumn{1}{|c|}{ Variabel } & T & Signifikansi & Keterangan \\
\hline (Constant) & $-0,097$ & 0,923 & \\
\hline Prosedur & 1,449 & 0,157 & Tidak Signifikan \\
\hline Pelayanan & 2,630 & 0,013 & Signifikan \\
\hline Pengetahuan & 0,757 & 0,455 & Tidak Signifikan \\
\hline
\end{tabular}

Sumber : Data SPSS telah diolah (2021)

\section{Pengaruh Prosedur Terhadap Keputusan Wajib Pajak UMKM Untuk Mengikuti Program Relaksasi Pajak}

Hipotesis 1: hasil tabel 14 menyatakan bahwa variabel prosedur (X1) nilai t hitung sebesar $1,449<\mathrm{t}$ tabel sebesar 1,69389 dan nilai Sig 0,157>0,05. Sehingga variabel Prosedur (X1) tidak berpengaruh signifikan terhadap keputusan wajib pajak UMKM mengikuti program relaksasi pajak (Y). Pada kondisi pandemi covid-19 ini kalangan pelaku usaha wajib pajak UMKM kurang memahami bagaimana prosedur untuk mengikuti program relaksasi pajak yang diselenggarakan oleh pemerintah. Dalam situasi ini pemerintah dinilai kurang dalam melakukan sosialisasi kepada para pelaku usaha wajib pajak UMKM. Namun pada penelitian ini tercatat data frekuensi responden wajib pajak UMKM yang terdampak covid-19 adalah sebesar $85,7 \%$. Sehingga didapatkan argumentasi responden pada penelitian ini mayoritas responden akan tetap berusaha untuk mengikuti program relaksasi pajak yang diselenggarakan oleh pemerintah guna mendapatkan keringanan dalam memenuhi kewajiban perpajakan mereka. Bahkan sesulit apapun prosedur yang harus dilalui oleh pelaku usaha wajib pajak UMKM tersebut. 


\section{Pengaruh pelayanan terhadap keputusan wajib pajak UMKM untuk mengikuti program Relaksasi Pajak}

Hipotesis 2 : hasil tabel 14 menyatakan variabel pelayanan (X2) nilai t-hitung senilai $2,630>\mathrm{t}$ tabel sebesar 1,69389 dan nilai sig 0,013<0,05. Sehingga variabel pelayanan (X2) berpengaruh signifikan terhadap keputusan wajib pajak UMKM mengikuti program relaksasi pajak (Y). Pada kondisi pandemi covid-19 ini kalangan pelaku usaha wajib pajak UMKM berpendapat bahwa pelayanan baik dan responsif terhadap pelaku usaha wajib pajak UMKM yang mengetahui manfaat serta berkeinginan untuk mengikuti program relaksasi pajak ini untuk meringankan kewajiban perpajakan mereka. Mengingat data yang diperoleh pada penelitian ini mayoritas terdampak covid-19 sebesar $85,7 \%$.

\section{Pengaruh Pengetahuan terhadap Keputusan wajib pajak UMKM untuk mengikuti program relaksasi pajak}

Hipotesis 3 : hasil tabel 14 menunjukkan jika variabel pengetahuan (X3) nilai t hitung sebesar $0,757<\mathrm{t}$ tabel 1,69389 dan value sig 0,455>0,05. Variabel pengetahuan (X3) tidak berpengaruh signifikan terhadap keputusan wajib pajak UMKM mengikuti program relaksasi pajak(Y). Pada kondisi pandemi covid-19 ini kalangan pelaku usaha wajib pajak UMKM berpendapat bahwa pengetahuan mengenai program relaksasi pajak yang diselengarakan oleh pemerintah kurang. Hal ini disebabkan oleh responden kurang mengerti tentang sosialisasi program relaksasi pajak yang diadakan oleh pemerintah. Yang nantinya berguna meringankan dalam pemenuhan kewajiban perpajakan selama masa pandemi covid-19. Sehingga indikator pengetahuan produk jasa berada di dalam kategori mengetahui secara baik (Yuliawan, 2011).

\section{Koefesien Determinasi}

Menurut Ghozali (2011) koefisien determinasi bertujuan mengeetahui seberapa besar variabel independen mumpuni mendeskripsikan dan mempengaruhi variabel terikat.

Tabel 15. Koefisien Determinasi Model Summary ${ }^{b}$

\begin{tabular}{|c|c|r|r|r|}
\hline Model & $\boldsymbol{R}$ & $\boldsymbol{R}$ Square & $\begin{array}{c}\text { Adjusted } \boldsymbol{R} \\
\text { Square }\end{array}$ & $\begin{array}{c}\text { Std. Error of } \\
\text { the Estimate }\end{array}$ \\
\hline 1 & $.872^{\mathrm{a}}$ & .760 & .736 & 3.14090 \\
\hline
\end{tabular}

Sumber : Data SPSS telah diolah (2021)

Hasil tabel 15 pada penelitian ini menyatakan bahwa $0,736 \times 100 \%=73,6 \%$. Sehingga keputusan wajib pajak UMKM mengikuti program relaksasi pajak dijelaskan 73,6\% oleh variabel prosedur, pelayanan, dan pengetahuan sisanya dijabarkan oleh variabel lainnya yang belum dimasukkan dalam penelitian ini.

\section{PENUTUP \\ Simpulan}

Riset ini menyatakan hasil jika variabel prosedur dan pengetahuan tidak berpengaruh signifikan terhadap keputusan wajib pajak UMKM mengikuti program relaksasi pajak. Sedangkan variabel pelayanan berpengaruh signifikan terhadap keputusan wajib pajak UMKM untuk mengikuti program relaksasi pajak. Keterbatasan riset ini ialah 3 variabel yang mencakup prosedur, pelayanan dan pengetahuan mampu menjelaskan nilai adjusted $\mathrm{R}^{2} 73,6 \%$ sedangkan sisanya sejumlah $26,4 \%$ dijelaskan oleh variabel lain yang kemungkinan dapat berpengaruh terhadap keputusan wajib pajak UMKM mengikuti program relaksasi pajak untuk mengikuti program relaksasi pajak. 


\section{REFERENSI}

Efriyenty, Dian dan Viola Syukrina E Janrosl. 2017. Analisis Faktor-Faktor yang Mempengaruhi Pengambilan Kredit Oleh Pelaku Usaha Kecil Menengah pada Debitur Bank Perkreditan Rakyat Kota Batam.

Ghozali, Imam. 2011. Aplikasi Analisis Multivariate Dengan Program IBM SPSS 19 EDISI 5. Semarang: Badan Penerbit UNDIP.

Ghozali, Imam. 2011. Aplikasi Analisis Multivariate Dengan Program IBM SPSS 21 Update PLS Regresi. Semarang: Badan Penerbit UNDIP.

Indonesia (2008). Undang-Undang Nomor 20 Tahun 2008 Tentang Usaha Mikro, Kecil dan Menengah (UMKM).

Indonesia (2020). Peraturan Menteri Keuangan Nomor 44/PMK.03/2020 Tentang insentif Pajak untuk Wajib Pajak Terdampak Pandemi Corona Virus Disease 2019. Jakarta: Menteri Keuangan.

K.Lely, Ni Aryani Merkusiwati, I Gusti Ayu Eka Damayanthi. 2018. Faktor-Faktor Yang Mempengaruhi Kemauan Wajib Pajak Mengikuti Tax Amnesty di KPP Pratama Kota Denpasar. Akuntabilitas: Jurnal Ilmu Akuntansi. Volume 11 (1), 2018: 1 - 22.

Kotler,P. (2002). Manajemen Pemasaran Edisi Millenium, Cetakan Kedua. Jakarta: PT Prenhallindo.

Lubis, R dan Mahalli, L, 2014. Analisis Faktor-faktor yang Mempengaruhi Pengusaha UMK untuk Menggunakan Jasa Pembiayaan Modal Kerja pada Bank Syariah di kota Medan. Jurnal Ekonomi dan Keuangan, 2(2).

Manuarang dan Mawardi, 2018. Pengaruh Product Knowledge terhadap Purchased Intention. Jurnal Administrasi Bisnis, 55 (3)

Mowen, J.C., dan Minor, M.S. (1998). Consumer Behavior and Marketing Strategy. New York : Mc Graw-Hill Companies.

Mulyadi. (2003). Sistem Akuntansi, Edisi Ketiga, Cetakan Keempat. Jakarta: Salemba Empat.

Othman, A. And L. Owen, 2001. Adopting And Measuring Customer Service Quality SQ In Islamic Banks: A Case Study In Kuwait Finance House. International Journal Of Islamic Financial Services, 3(1): 100 -126.

Peter, J Paul dan Olson, Jerry C. (2010). Consumer Behavior: Perilaku Konsumen dan Strategi Pemasaran, Edisi keempat. Jakarta: Erlangga.

Tjiptono, F. (2007). Strategi Pemasaran. Yogyakarta: Andi Offset.

Yuliawan, eko, 2011. Pengaruh Pengetahuan Konsumen Mengenai Perbankan Syariah terhadap Keputusan Menjadi Nasabah pada PT. Bank Syariah Cabang Bandung. Jurnal Wira Ekonomi Mikroskil, 1(1).

Bisnistempo.com

Covid19.go.id

Kemenkeu.go.id

Merdeka.com

Patrolipost.com

www.depkop.go.id

www.kemenkopukm.go.id 